\title{
SURVEI $p H$ SALIVA PADA ANAK RETARDASI MENTAL DI SLB KABUPATEN JEPARA TAHUN 2016
}

\author{
Erni Mardiati $^{\bowtie 1}$, Irma H.Y. Siregar ${ }^{2}$, Tika Dui Dara Ayuningtiyas ${ }^{3}$
}

\begin{abstract}
ABSTRAK
Retardasi mental adalah kelainan keterbelakangan fungsi intelektual dan kemampuan adaptif yang signifikan dengan tanda-tanda yang ditunjukkan sebelum usia 18 tahun. Penderita retardasi mental memiliki kesehatan dan kebersihan mulut yang lebih buruk dibandingkan dengan anak yang normal. Tujuan penelitian adalah untuk menentukan keadaan penyangga air liur pada anak-anak cacat mental di SLB Kabupaten Jepara.

Penelitian survei. Menggunakan rancangan cross sectional, dan sampling menggunakan stratified random sampling, jenis yang digunakan peneliti untuk mengetahui beberapa variabel dalam populasi, karena jumlah siswa di SLB Kab. Jepara 225 dan peneliti mendapatkan 20\% dari total jumlah siswa adalah 45, dan dikelompokkan menjadi 15 orang dengan retardasi mental ringan, keterbelakangan mental 15 orang dengan moderat dan 15 dengan keterbelakangan mental yang berat.

pH saliva pada anak retardasi mental cenderung lebih asam sebagai pendapat para peneliti, disebabkan oleh sekresi pH saliva kurang maksimal karena pekerjaan aktivitas saraf otonom yang meliputi simpatis dan parasimpatis saraf. Hasil penelitian menunjukkan bahwa rata-rata $\mathrm{pH}$ saliva air liur pada retardasi mental di Kabupaten Jepara tertinggi di SLB menunjukkan pH saliva asam 67\% dan terendah pada pH saliva kategori basa sebesar $13 \%$.

Kesimpulan menyarankan orang tua untuk lebih memperhatikan tentang kebersihan gigi anak-anak, dan melatih anak-anak untuk selalu menjaga kebersihan sendiri, terutama dalam hal kesehatan mulut, juga bisa mengajarkan cara menyikat gigi. Bagi sekolah tersebut membuat program kesehatan gigi upaya di sekolah dengan programyang dapat diterapkan untuk anak retardasi mental, seperti menyikat gigi bersama-sama atau melakukan pemeriksaan rutin setiap 6 bulan.
\end{abstract}

Kata kunci : Retardasi Mental, pH Saliva

\begin{abstract}
Mental retardation is a retardation abnormality intellectual functioning and adaptive capabilities significantly with the signs shown before the age of 18 years. People with mental retardation have oral health and hygiene were worse compared with normal children. Purpose of this study was to determine the state of buffer of saliva in mentally retarded children in SLB Jepara.

This research is a survey and cross sectional study as research design, and sampling using stratifiedrandom sampling. This type is used by researcher to know some of the variables in the population, because the total number of students in SLB Jepara was 225 and researchers get $20 \%$ of the total number of students is 45 , and are grouped into 15 people with mild mental retardation, 15 people with moderate mental retardation and 15 with severe mental retardation.

pH saliva of mentally retarded children tend to be more acidic, is caused by the exclusion or secretion of buffer saliva is less than the maximum because of the work of the autonomic nervous activity which includes the sympathetic and parasympathetic nervous. The results showed that the average $\mathrm{pH}$ of saliva in children with mental retardation in Jepara regency highest in SLB show in an acidic state by $67 \%$ and the lowest is in the alkaline state in the amount of $13 \%$. Parents need to pay more attention to hygiene and dental health of children, and also train children to always keep his own personal hygiene, especially in terms of oral health, it could also teach brushing teeth early. And the researchers suggested that the school makes an effort dental health program in schools with programs that can be applied to children with mental retardation, such as brushing their teeth together or perform routine checks every 6 months.
\end{abstract}

Keywords : Mental retardation, $p H$ Saliva

$\overline{1,2)}$ Dosen Jurusan Keperawatan Gigi Poltekes Kemenkes Semarang

${ }^{3)}$ Mahasiswa Jurusan Keperawatan Gigi Poltekkes Kemenkes Semarang

$凶$ : erni.mardiati@gmail.com 


\section{PENDAHULUAN}

Menurut Nyumirah (2013), Kesehatan jiwa adalah suatu kondisi sehat emosional, psikologis, dan sosial yang terlihat dari hubungan interpersonal yang memuaskan pada perilaku individu yang lebih efektif, konsep diri yang positif serta kestabilan emosional. Kesehatan jiwa juga mempunyai sifat yang harmonis dan memperhatikan semua segi dalam kehidupan manusia dalam berhubungan dengan manusia lainnya yang akan mempengaruhi perkembangan fisik, mental, dan sosial individu secara optimal yang selaras dengan perkembangan masing-masing individu.

Retardasi mental adalah disabilitas yang dicirikan dengan keterbatasan bermakna baik dalam fungsi intelektual dan dalam keterampilan adaptif seperti yang ditunjukan dalam keterampilan adaptif konseptual, sosial, dan praktik. Keterbelakangan mental atau disebut retardasi mental (RM) adalah suatu keadaan dengan intelegensia yang kurang (subnormal) sejak masa perkembangan (sejak lahir atau sejak masa anak-anak). Biasanya terdapat perkembangan mental yang kurang secara keseluruhan, tetapi gejala utama ialah intelegensi yang terbelakang. Retardasi mental disebut juga oligofrenia $($ oligo $=$ kurang atau sedikit dan fren $=$ jiwa $)$ atau tuna mental. Keadaan tersebut ditandai dengan fungsi kecerdasan umum yang berada dibawah rata-rata dan disertai dengan berkurangnya kemampuan untuk menyesuaikan diri. (Betz and Showden, 2009).

Retardasi mental sebenarnya bukan suatu penyakit walaupun retardasi mental merupakan hasil dari proses patologik di dalam otak yang memberikan gambaran keterbatasan terhadap intelektualitas dan fungsi adaptif. Retardasi mental dapat terjadi dengan atau tanpa gangguan jiwa maupun gangguan fisik lainnya. Pada umumnya pasien dengan retardasi mental memiliki kesehatan rongga mulut dan oral hygiene yang lebih rendah dibanding dengan orang tanpa cacat perkembangan.

Data pasien dengan retardasi mental memiliki karies lebih banyak dan prevalensi gingivitis yang lebih tinggi serta penyakit periodontal lainnya dibanding dengan masyarakat umum. Gingivitis ringan diakibatkan oleh suatu akumulasi bakteri plak dan terjadinya peradangan, serta pembengkakan gusi yang mudah berdarah. Pasien dengan retardasi mental memiliki peningkatan karies yang sama dengan orangorang tanpa keterbelakangan mental. Meskipun demikian, prevalensi karies gigi yang tidak dirawat lebih tinggi pada pasien dengan retardasi mental terutama bagi mereka yang tinggal di lingkungan yang tidak mendukung. Prevalensi maloklusi pada pasien dengan retardasi mental serupa dengan yang ditemukan pada masyarakat umum. Hampir 25\% dari $80 \%$ kelainan anomali kraniofacial dapat mempengaruhi perkembangan oral yang di hubungkan dengan retardasi mental.Gigi yang berjejal atau keluar dari lengkung rahang lebih sulit untuk menjaga kebersihannya, menyebabkan penyakit periodontal dan karies gigi (Salmiah, 2010).

Retardasi mental merupakan kelainan keterbelakangan fungsi intelektual dan kemampuan adaptif yang signifikan dengan tanda-tanda yang ditunjukkan sebelum usia 18 tahun. Penderita retardasi mental memiliki kesehatan dan kebersihan mulut yang lebih buruk dibandingkan dengan anak yang normal. Dijumpai tingginya prevalensi karies gigi, gingivitis dan periodontitis. Selain itu, penderita retardasi mental mempunyai karies gigi yang parah.Karies gigi terjadi melalui pembentukan plak kariogenik pada permukaan gigi yang dapat menurunkan $p H$ saliva hingga $p H$ kritis sehingga menyebabkan demineralisasi gigi (Rizqi, 2013).

Berdasarkan studi pendahuluan yang telah dilakukan pada hari Senin, tanggal 23 November 2015 di SLB Kab Jepara menyatakan bahwa hampir sebagian anak retardasi mental cenderung mempunyai status kerusakan gigi yang parah. Hal 
tersebut bisa dipengaruhi oleh faktor keasaman $p H$ Saliva dan juga faktor kurangnya kemampuan untuk menjaga kebersihan gigi dan mulut. Tujuan penelitian ini ingin mengetahui keadaan $p H$ Saliva Anak Retadasi Mental.

\section{METODE PENELITIAN}

Jenis penelitian yang digunakan adalah penelitian Survei, atau penelitian noneksperimen. Rancangan penelitian menggunakan Cross Sectional yang merupakan suatu penelitian untuk dinamika korelasi antara faktor-faktor resiko dengan efek, dengan cara pendekatan observasi atau pengumpulan data secara simultan (dalam waktu yang bersamaaan) (Notoadmojo, 2010).

Populasi dalam penelitian ini adalah siswa yang mengalami retardasi mental di SDLB kabupaten jepara yang berjumlah 225 siswa yang terdiri dari beberapa kategori mulai dari kelas 1-6. Sampel adalah sebagian dari populasi yang diteliti (Arikunto, 2006). Teknik Pengambilan sampel menggunakan teknik Stratified Random Sampling, Jenis sampling ini digunakan peneliti untuk mengetahui beberapa variabel pada populasi (Nursalam, 2013). Sampel sebanyak 45 orang dan dikelompokkan menjadi 3 kelompok dengan anggota 15 orang, yaitu kategori tingkat retardasi mental ringan, retardasi mental sedang, dan retardasi mental berat secara acak.

Menganalisis data menggunakan metode analisis deskriptif yaitu suatu prosedur pengolahan data dengan menggambarkan dan meringkas data secara ilmiah dalam bentuk tabel atau grafik. Datadata yang disajikan meliputi frekuensi, proporsi, dan rasio, Salah satu pengamatan yang dilakukan pada tahap analisis deskriptif adalah pengamatan terhadap tabel frekuensi dan persentase untuk setiap kategori. (Nursalam, 2013).

\section{HASIL DAN PEMBAHASAN}

Berdasarkan hasil penelitian yang dilakukan di SLB Negeri Kabupaten Jepara terdapat 45 sampel, dengan pembagian sampel per kategori sebagai berikut:

Tabel 1. Distribusi frekuensi $p H$ Saliva pada anak retardasi mental di SLB Kabupaten Jepara Tahun 2016

\begin{tabular}{|c|c|c|c|c|c|c|c|}
\hline \multirow{3}{*}{ Kriteria } & \multicolumn{6}{|c|}{ Kategori Retardasi Mental } & \multirow{3}{*}{$\begin{array}{c}\text { Rata-Rata } \\
\text { Kriteria } \\
\text { pH Saliva }\end{array}$} \\
\hline & \multicolumn{2}{|c|}{$\begin{array}{c}\text { Retardasi } \\
\text { Mental } \\
\text { Ringan }\end{array}$} & \multicolumn{2}{|c|}{$\begin{array}{c}\text { Retardasi } \\
\text { Mental } \\
\text { Sedang }\end{array}$} & \multicolumn{2}{|c|}{$\begin{array}{c}\text { Retardasi } \\
\text { Mental Berat }\end{array}$} & \\
\hline & $\mathrm{f}$ & $\%$ & $\mathrm{f}$ & $\%$ & $\mathrm{f}$ & $\%$ & \\
\hline Asam & 11 & 74 & 9 & 60 & 10 & 67 & 67 \\
\hline Netral & 2 & 13 & 4 & 27 & 3 & 20 & 20 \\
\hline Basa & 2 & 13 & 2 & 13 & 2 & 13 & 13 \\
\hline Jumlah & 15 & 100 & 15 & 100 & 15 & 100 & 100 \\
\hline
\end{tabular}

Berdasarkan tabel diatas, dapat dilihat bahwa rata-rata prosentase $p H$ Saliva anak retardasi mental yang paling tinggi adalah pada keadaan asam dengan prosentase $67 \%$ dan pada keadaan paling rendah adalah keadaan basa yaitu sebesar $13 \%$.

Berdasarkan hasil penelitian yang dilakukan pada siswa retardasi mental di SLB Negeri Kabupaten Jepara diketahui bahwa kondisi $p H$ Saliva pada anak retardasi mental kriteria ringan, cenderung lebih tinggi daripada $p H$ Saliva anak retardasi mental kriteria sedang dan berat, sedang keadaan dengan $\mathrm{pH}$ asam, pada anak retardasi mental ringan memiliki prosentase $p H$ Asam sebesar $74 \%$ dan anak retardasi mental sedang sebesar $60 \%$ dan anak retardasi mental berat sebesar $67 \%$, hal ini disebabkan karena pada penderita retardasi mental cenderung mengalami xerostomia (produksi ludah yang kurang). Menurut Fatia (2011), menyatakan bahwa penderita retardasi mental adalah suatu keadaan atau kondisi fisiologis tersebut dapat mempengaruhi sekresi saliva oleh syaraf simpatik dari sistem syaraf autonom dan menghalangi sistem parasimpatik yang menyebabkan turunnya sekresi saliva, di mana mulut akan kering dan menyebabkan xerostomia. 
Pada penelitian ini di dapatkan hasil rata-rata $p H$ Saliva anak retardasi mental cenderung lebih asam karena menurut pendapat peneliti hal ini disebabkan oleh pengeluaran atau sekresi $p H$ Saliva yang kurang maksimal karena faktor dari aktivitas kerja saraf otonom yang meliputi saraf simpatik dan parasimpatik. Sependapat juga dengan Syaiffudin (2006) saraf simpatik dan parasimpatik merupakan bagian dari saraf otonom yang bekerjanya tidak disadari dan bekerja secara otomatis.

Saraf simpatik bekerja merangsang sekresi тисиs sedangkan parasimpatik merangsang sekresi serous pada kelenjarkelenjar saliva. Pada penderita retardasi mental adanya kelainan genetik yang berpengaruh pada intelegensi dan kerja saraf otak memungkinkan adanya kelainan pula pada kerja saraf simpatik dan parasimpatik yang dapat mempengaruhi keseimbangan sekresi saliva tersebut. Perubahan sekresi saliva tersebut dimungkinkan dapat mempengaruhi $p H$ dan buffer saliva penderita retardasi mental. (Rizqi, 2013)

Menurut merinda (2013) laju sekresi saliva yang tinggi akan menyebabkan kapasitas buffer menjadi tinggi, sehingga $\mathrm{pH}$ Saliva pun akan meningkat (Basa). begitu pula sebaliknya jika sekresi saliva rendah akan menyebabkan kapasitas buffer menjadi rendah, sehingga $p H$ Saliva pun akan menurun dan menyebabkan asam. Sedangkan rata-rata $p H$ Saliva paling rendah adalah pada keadaan basa yang bisa disebabkan karena sebagian dari responden memiliki kelainan dalam hal berkomunikasi, makan dan bahkan menelan, dari hal tersebut dapat mengakibatkan anak retardasi mental mengalami drooling (Ngiler) hal ini di dukung dengan pernyataan (judarwanto, 2012) yang menyatakan bahwa sekitar $10 \%$ anak-anak dengan keterbelakangan mental, drooling (Ngiler) mungkin menjadi sekunder untuk keterlambatan dalam perkembangan gerakan menelan terkoordinasi, efisien dan jarang menelan, kurangnya kesadaran ketidakmampuan lisan, dan penutupan bibir tidak sempurna saat menelan.

\section{KESIMPULAN}

1. Nilai tertinggi $p H$ Saliva anak retardasi mental ringan ada pada kondisi asam sebesar 74\% dan paling rendah pada kondisi basa dan netral sebesar $13 \%$.

2. Nilai tertinggi $p H$ Saliva anak retardasi mental sedang ada pada kondisi asam sebesar $60 \%$ dan $\mathrm{pH}$ paling rendah ada pada kondisi basa sebesar $13 \%$

3. Nilai tertinggi $p H$ Saliva anak retardasi mental berat ada pada kondisi asam sebesar $67 \%$ dan $p H$ paling rendah ada pada kondisi basa sebesar $13 \%$.

4. Nilai tertinggi rata-rata $p H$ Saliva anak retardasi mental sebesar $67 \%$ pada keadaan asam, dan terendah sebesar $13 \%$ pada keadaan basa.

\section{DAFTAR PUSTAKA}

Arikunto, S., 2006, Prosedur Penelitian Suatu Pendekatan Praktik, Jakarta: PT Rineka Cipta. (Hal : 130-134).

Betz, L.C., and showden, 2009, Buku saku keperawatan pediatri; (Penerjemah: Ns. Eny Meiliya, S.Kep). Jakarta: EGC. (Hal : 407-409)

Dwiastuti, N., 2012. Perbedaan pH Saliva Antara Perokok dan Bukan Perokok pada Mahasiswa Teknik Mesin Universitas Muhammadiyah Surakarta, http://eprints.ums.ac.id. Diakses 18 Januari 2016.

Fatha, E.M., 2015, Perbedaan Status Kesehatan Gigi dan Mulut Anak Retardasi Mental Ringan dan Sedang di SDLB Kota Jepara Tahun 2015, Karya Tulis Ilmiah, Poltekkes Kemenkes Semarang. (Hal : 28-29)

Fatia, B.M., Novia, J., dkk, 2011, Mulut Kering, http://dentacrab.blogspot.co.id. Diakses 13 Juni 2016. 
Judarwanto, W., 2012, Penanganan Sialore, Kebiasaan Ngiler Pada Anak, https://dokterindonesiaonline.com. Diakses 25 Januari 2016.

Merinda, W., Endahyani, D.E., dkk, 2013, Hubungan pH dan Kapasitas Buffer Saliva terhadap Indeks Karies Siswa SLB-A Bintoro Jember (The Correlation between Salivary $\mathrm{pH}$ and Buffer Capacity with Caries Index of Students in SLB-A Bintoro Jember), repository.unej.ac.id. Diakses 31 April 2016.

Notoadmodjo, S., 2010, Edisi revisi: Metodologi Penelitian Kesehatan, Jakarta: PT Rineka Cipta. (Hal : 2526)

Nursalam, 2013, Metodologi Penelitian Ilmu Keperawatan, Jakarta: Salemba Medika. (Hal : 173-174).

Nyumirah, S., 2013. Peningkatan Kemampuan Interaksi Sosial (Kognitif, Afektif, dan Perilaku) Melalui Penerapan Terapi Perilaku Kognitif di RSJ DR Amino Gondohutomo Semarang, http://download.portalgaruda.org/.

Diakses 18 Januari 2016.

Rizqi, F., 2013, Hubungan pH dan Buffer Saliva dengan Indeks DMF-T pada Siswa Retardasi Mental SLB-C TPA Jember(Correlation $p H$ and Buffer Saliva with DMF-T Index on Mental Retardation Students SLB-C TPA Jember), http://repository.unej.ac.id. Diakses 24 November 2015.

Salmiah, S., 2010, Retardasi Mental, http://repository.usu.ac.id. Diakses 23 November 2015.

Syaiffudin, 2006, Anatomi Fisiologi untuk Mahasiswa Keperawatan, Jakarta, EGC. (Hal : 302-303).
Wikipedia , 2015, Karies Gigi, https://id.wikipedia.org. Diakses 26 Januari 2016.

Wong, D.L., 2008, Buku Ajar Keperawatan Pediatrik Wong; (Penerjemah: Agus Sutarna, S.Kp, MNSc, Neti Juniarti, S.Kp, dr. H.Y. Kuncara). Jakarta: EGC. (Hal : 705) 